\title{
The Power of EFL Teacher's Beliefs to Drive Practice
}

\author{
Suwarsih Madya \\ Yogyakarta State University, Indonesia
}

\section{How to cite}

Madya, S. (2019). The Power of EFL Teacher's Beliefs to Drive Practice. Asia Pacific Journal on Curriculum Studies, 2(1), 7-18. https://doi.org/10.53420/apjcs.2019.2

\begin{abstract}
In a test-driven instructional development such as that in Indonesia, teachers spend most of his time, energy, and thoughts to strive for his students' excellent performance in the final test. This is due to the indicator used to judge the success of a school. One particular teacher of English is, however, different. I have collected data on his class and conducted an in-depth interview with him. The results of data analysis revealed that the teacher is creative and innovative as he strives to help his students of different levels and types of abilities to make as high achievements as they can. In other words, he strives to enable their students to reach their full potential development. He is also very productive, with more than 180 books as his works and creative and innovative in his teaching, enabling his students to speak English fluently in communicative situations evidenced in their performance in the final test of speaking witnessed by the students' parents. This particular teacher is a rare asset in the development of English language teaching. More importantly, he confessed that his strong beliefs in students have driven him to do his best to facilitate his students' learning. This is in line with the findings of numerous research studies. This implies the importance of developing and strengthening the teachers' beliefs through redesigning the English language teacher education curriculum, both pre-service and in-service.
\end{abstract}

Keywords: instructional design, instructional assessment, English as Foreign Language (EFL)

\section{Introduction}

Compared with other foreign languages, English has a special place in Indonesian education. It has been the only foreign language taught as a compulsory subject in secondary and tertiary education since the beginning of the Republic. Other languages are also taught but as elective subjects. The choice of English as the first foreign language is related among others to practical purposes of education (e.g. using scientific books written in English, publishing research report in international journals, and sending citizens to study abroad), economic purposes (international trading, tourism), foreign cooperation purposes, and diplomatic purposes (also see Lauder, 2008).

The aim of teaching English has shifted following the societal developments. In the past, priority was to be given to receptive English skills, i.e. reading and listening (Decree of the Ministry of Education and Culture No. 096/1967, of 12 December 1967, as cited in Madya, 1987). However, from the middle of 1980s to the first half of the first decade of the 21st century increasing attention was paid to productive English, with the implementation of the communicative approach (Sadtono, 2007; 2008). Then from 2006 onwards, the production of English texts has been the goal of teaching English in secondary schools as can be seen from the formulation of graduate exit competence. However, the goal of teaching English as a foreign language (EFL afterward) in Indonesia's linguistically diverse situation is still far from being reached.

In some situations, the teaching of EFL has been successful with the students' English proficiency as an indicator, but in general it has not fully been achieved its declared goal nation-wide. Examples of success have been reported as achieved in an Islamic Boarding School (Mahmud, 2017), in an English basecamp (Ahsanu, Februansyah, and Handoyo, 2014), in a senior high school (Irambona \& Komaidi, 2015), in a private elementary school (Kartikarini, 2020), and a private secondary boarding school (Ataveva, 2020). In all these situations, the teaching is not merely oriented to the high-stake national test, but to the development of students' proficiency. However, nationwide the students' English proficiency as the goal of teaching EFL at school has not been achieved due to unfavourable factors. The first one is the scarcity of English exposure outside the school due to the status English as a foreign language; exposure to English in its authentic use is very limited, if any at all (Lauder, 2008). Another crucial issue is the low to medium level of English proficiency among EFL teachers as assumed by Renandya, Hamied, and 
Nurkamto (2018) and found through a research study by Lie et al. (2019). The latter found that teachers experienced a loss of proficiency after 15 years of teaching. This is closely related to the scarcity of opportunity for every EFL teacher to practice it outside the school and to have in-service training. This has certainly complicated the situation. Another important factor is the assessment system, which pays very little attention, if any at all, to the assessment of English productive skills. This has led most of the teachers to focus their teaching on matters being tested nationally. Sulistyono $(2009 ; 2015)$ called such a factor as the teaching focus. In short, the teaching of English in Indonesia badly needs improving.

Unfavorable factors have caused the failure of teaching EFL nationwide as has been observed by English language teaching experts (Renandya, 2004; Lengkanawati, 2005; Widiati \& Cahyono, 2006; Marcelino, 2008; Mattarima \& Hamdan, 2011; Yusny, 2013; Yulia, 2013; Sulistiyo, 2015; Songbatumis, 2017). These factors include class size, student motivation, and teaching focus (Sulistiyo, 2015), the absence of a unified system of EFL teaching, inappropriate methods (Marcelino, 2008), and the quality of teachers (Lubis, 2018; Anugerahwati \& Saukah, 2010). My in-depth interviews with postgraduate students who are also teachers attending my class in the last 5 years have indicated that the teaching of EFL has not reached the declared goal, i.e. the ability to use English to communication purposes. In short, teachers of EFL still have to work harder as English has become a lingua franca in the world.

In such a situation, EFL teachers are obliged to answer greater challenges. The latest curriculum has an explicit new mandate of content categories - the 18 character values, HOTS and the 4CS into their teaching. They are then obliged to integrate these content categories into their teaching. The teaching HOTS and 4CS is demanded by the global development, whereas the instilment of the character values is related to the message in what is meant by education and in the function and goal of national education formulated respectively in Article 1 and Article 3 of the 2003 Education Act. Form these two articles can be derived the following four points: (a) students as subjects of their own learning; (b) the development of their whole potentials; the fulfilment of students' own needs, community's needs, and nation's needs; and teachers as facilitators. All the content categories can be integrated well through applying a communicative approach extended eclectically into the genre-based pedagogy to include intercultural learning and critical literacy (Hyland, 2007; Kumar, 2013; Leeds-Hurwitz, 2013; Lazarus \& Beutler, 1993; Mellow, 2002; Richards, 2006: 22-23).

This formulation of the function and goal of education has been based in the Five State Principles, of which the first is Belief in One God with His Perfect Oneness. It is rooted in this principle that the most outer circle in the layers of educational contexts is the hereafter context. I strongly believe that this principle, when applied consistently, will ensure that everything is going on in the right tract, observing justice and equality. It should always be remembered, though, that at all levels of education, building a good character is the heart of education by observing the same basic values such trustworthiness, respect, responsibility, fairness, caring, citizenship, part of which are the 18 character values mentioned above.

I myself share Martin Luther King's view that intelligence plus character is the goal of true education, but go further to say that character, in which intelligence is inherent, is the last true destiny of all educational journeys. By saying this I mean that all of what has been learned in the four domains of learning - cognitive, affective, psychomotor, interactive (Romizowsky, 1981) should be transformed into wisdom, which is expressed in the whole character. Accompanying this view is my strong belief that the sustained observation of values is ensured if the control rests in the heart and mind of the person with a commitment to being held accountable to the people concerned in this world and to God the Almighty, the Most Merciful, the Creator, the Knower of the unseen, the Superior, later in the eternal hereafter. This is another dimension of character, which is more spiritual, of which the positive impact will reach all creatures, be living or non-living, in this world. So, the teaching of English in Indonesia should support the development of intelligences embedded in the whole character. This is of course the desired condition of which the achievement needs the orchestra of all stakeholders.

What has been going on in practice? Through my interaction with EFL teachers in Yogyakarta Special Province in some occasions, and EFL teachers doing further studies, both in the Master's and doctoral levels, in my university in the last 13 years, I have got information that:

1. In general they believe that the best thing to do is by complying with the curriculum policy, which encourages them to be creative in meeting the students' learning needs, which vary with their characteristics (ability, learning styles, personality, life experiences).

2. However, they face two dilemmas: (a) the curricular demand for developing the productive skills on the one hand and demand for a big success in the high-stake national exam which is limited to the receptive skills as the criterion of the school achievement; and (b) the demand for developing HOTS and instilling character values, which certainly absorbs a lot of time on the one hand and the demand for paying special attention to the national exam. 
3. This problematic situation is worsened when the supervisor has a different educational background (no English education background).

The first two issues above will remain critical unless the EFL teachers stop thinking dichotomously and start thinking integratedly instead. In other words, the declared goal of teaching EFL, which is the ability to use spoken and written English for effective communication purposes in real life situations, is still far away from being accomplished if there is no strong will and belief to change. The third issue can create some tension in the relationship between the teachers as the supervisees and the supervisor, which may negatively impact the former's performance. With these three issues remaining critical, it will be very difficult, if not impossible, to improve the situation if teachers do their business as usual. The present situation is in general still far away from desired.

However, amidst my mixed feelings of high expectations and worries of failing to meet them, I have caught a glimpse of hope. I have noticed one particular teacher who is different from the rest. I have observed him during his teacher education studies in which he joined my undergraduate classes and wrote his Master's thesis under my supervision. Keeping professional contacts with him, I have observed his professional development and achievements. From our communication, I can notice his consistent efforts to help his students to learn English and develop their character. So, I decided to explore to find out what has made him different from other teachers.

This study was aimed at exploring as a case this particular teacher, a very senior teacher working in a senior high school in a small town. I have regarded him as very special based on his outstanding achievements, which have been well publicized through mass media. The questions to be answered in this study were: What has driven this teacher to teach and educate differently from other teachers? How does he carry out his teaching?

\section{Method}

Considering that what is in one's head is the source of action, the study started with an exploration of what is his mind, and then how he enacts it in his classroom. To collect data, I did the following in order: in-depth interviews, discussions, document/records analysis, and observation. I checked the dependability by repeating the interviews with time intervals while observing the professional communication between them and their colleagues through a social medium (the English Teacher Association WhatsApp Group). I also visited his class and talked with the students to triangulate the information. I analyzed the data through data condensation (finding consistent patterns of the two teachers' verbal and non-verbal behaviors), data display (presenting the description) and drawing conclusions (Huberman, Miles \& Saldana, 2014).

\section{Results and Discussion}

The results of data analysis indicated that the researched teacher has strong beliefs about the students, teacher's duty, curriculum, about learning, and technology. These beliefs have guided him to act in his classroom. The findings are presented below.

The teacher's beliefs. From the in-depth interviews, I got information as follows. The researched teacher, with 36 years of teaching experiences, claimed that despite the high-stake national exam, he had managed to (a) concentrate on finding ways of helping his students to learn to use English both in oral and in written forms, receptively and productively; (b) make efforts to make his students realize that the English productive skills are a part of the life skills which can brighten their future; (c) observe that the success of his students to acquire such skills at a certain stage had increased their motivation to learn, leading to another success (a sort of self-rewarding-related motivation); and (d) instill in his students the values of hard work, diligence, perseverance, discipline, honesty, and being visionary, necessary to support their success in their future life. He said that these values matched perfectly with the technical skills to form life skills in the true sense. Below are his strong statements I will discuss one by one in the light of the theories and findings of the previous studies.

a. I strongly believe that every student can learn English successfully if the teaching lends support.

b. Therefore, I feel obliged to make any effort to help them learn. I don't just rely on what the curriculum prescribes about ways of teaching. Instead, I use various methods to meet the students' learning needs but with a clear and realistic goal, i.e. the students' skills in using English for communication purposes. I make as many efforts as I can to achieve this goal. My students' learning success is my priority. I therefore read a lot of resources and attend seminars/workshops to find inspiring ideas and adapt them innovatively for my own teaching situation. I have proven that my eclectic approach is effective as evidenced in the achievement of that goal. 
c. The biggest constraint I have often faced is the school culture, which is sometimes not conducive to innovation, especially when the leaders (the Principal and Vice-Principals) just follow what is prescribed in the curriculum, which is often changed. However, instead of problematizing this situation, I'd rather concentrate on creating my own ways of teaching, of which the result is evidenced in my students' skills to use English productively, and even in the national exam. In my observation, people will eventually appreciate my efforts when they see the evidence of success in the form of students' English observable performance, which is scarcely found in other schools.

d. Mastering the four language skills is a must, but should not be an end in itself. It is a means to another end, which is the students' whole development (personal, academic and/or professional), necessary for their future careers.

e. I also strongly believe that students need to observe important values and develop learning skills. This can be integrated into the teaching of English through various models for learning. PBL (project-based learning) is one approach that can facilitate the instilment of values such as independence, self-discipline, diligence, perseverance, cooperation, communication, collaboration, caring, respect, justice, and responsibility.

f. I set the rules together with my students. When they fail to complete a task on time (e.g. reading English stories and make a summary), they are required to translate a story. In this way, they work hard to meet the deadline. I often remind them that self-discipline is a prerequisite for a successful life.

g. I encourage every student to have a sort of personal ideal in their life and they have to strive to achieve it. Learning English successfully is one of the possible endeavors to support the achievement of the ideal.

h. To my observations, my students are happy to answer the challenge I pose to them. They are happy to be involved in an English project (PBL). To my greatest pride, they are also happy to sit the open and video-taped oral exam in front of their parents. The advancement of technology is amazing, but to me technology is a means only, and the teacher should remain to be the architect of the whole business of teaching.

i. The greatest satisfaction as a reward to me is my success of helping lesser ability students to master English skills.

Referring to Rokeach (1972) and Pourhosein Gilakjani (2012), the teacher expressed his belief in a premise starting with "I believe that ...". What is stated in Point a shows that he applies the principle of mastery learning in which the students' mastery of the target competence is held constant and others aspects are adapted and adjusted for the sake of such mastery. Point $b$ is in line with Borg's (2001) statement that a belief, be it held consciously or unconsciously, is regarded as true by the persons and guides thought and behavior. It is also in line with Rocane (2015) who found that the teacher with strong pedagogical belief is motivated to offer students new opportunities. In the present study, the teacher's belief has guided him to develop into a truly professional teacher, applying the principles of 'peak performers' (Brown and Lee, 2015: 543): believe in himself (point a), set realistic goals (b), set priorities (point b), take calculated risk (point c), and reduce and manage stress factors (point c). The teacher also strives to achieve the curriculum goal, which is the students' ability to use English communicatively, both receptively and productively, as mentioned at the beginning of this paper. This is evidenced in the students' English proficiency described below. In other words, the teacher has in fact strived to help his students master English communicative competence (Celce-Murcia, 2007), and even gone beyond it to reach the instilment of some character values (points $d$ and e), which is the curricular mandate as mentioned earlier.

Considering the values the teacher mentioned in point e, I would say that he covers in his teaching practice the instilment of performance values or "willing values" (independence, self-discipline, diligence, perseverance, cooperation, communication, collaboration) and moral character values (caring, respect, justice, and responsibility) (Davidson, 2004). Point f implies that he cares for the students' responsibility; they are trained to be responsible for what they have decided in making the rules. This is a good point from the point of view character education because the strength of one's character is reflected in his/her ability to make decisions and commitment to implementing them. Point $\mathrm{g}$ implies that he cares for the importance of being purposeful in life. Striving to reach the ideal in combination with the teaching of English implies that he cares for the importance of integrating different steps towards the same goal.

In reference to Vygotsky's (1978) ZPD (zone of proximal development), point h indicates that the teacher provides an appropriate challenge, which will facilitate the students' learning to reach their potential development. Therefore, the students enjoy the challenge. The video-taped oral English exam in front of the parents could be very challenging for students, but his students have done it willingly and performed confidently. It is a rare achievement worth further studying.

The teacher also indicated an appropriate attitude toward technology as implied in point i. He recognized the potential contribution of technology as an enabling tool, but he confirmed his preference to human touch. This is in line with Toyama (2011) who stated that "There are technology shortcuts to good education."

The teacher will be happy to read the author's statement that "Finland is among the countries that routinely perform at the top on PISA, and it is renowned for its low-tech, high-touch approach that emphasizes educational basics and relatively few hours of 
school or homework." The teacher's success in helping his students to achieve a relatively high level of English proficiency might be attributable his high-human touch.

Point $\mathrm{j}$ indicates the teacher's commitment to serving all students, while but paying special attention to students of lesser ability. This is an interesting phenomenon because as found in Khasanah's (2018) study on the zoning policy, the teachers and principals of the junior secondary schools researched tended to prefer students of high ability without considering that junior secondary education is compulsory so that everyone must be admitted and served as well as it can be. My conversation with postgraduate students who returned to campus to study also confirmed this. The 's researched teacher's strong belief was supported by his special satisfaction of successfully helping students of lesser ability. In this case, the teacher had a high level of interpersonal competence. That is, he "values opinions and abilities of students, is patient in working with students of lesser ability ..." (Brown \& Lee, 2015: 547).

My own experience in teaching high school students of lesser ability and low motivation also confirmed the belief that all students can learn English is the teaching lends support. That was at the beginning of my career as a secondary EFL teacher educator. I felt the need for teaching experience so that I could help my students understand the theories of teaching by giving concrete examples. I therefore decided to accept the offer to replace my friend who resigned from a private school as a part-time teacher. I started teaching with my readiness to help students learn. Knowing me teaching in the known unfavorable four first year classes (A, B, C, D), some teachers cautioned me about possible failures in these classes. They said that the students were uncontrollable and had no motivation to learn. I was grateful for such a caution. I prepared myself-heart and mind to touch the students' soul. In each class, I started with a conversation to explore what they thought about English and how teach it. I gave them freedom to speak out. In short, I managed to win their hearts and reached an agreement to start a lesson with a small vocabulary review test. After all, they soon found that they could do learn English though limited to vocabulary found in the learning materials. Within three weeks, all of them became cooperative and began to like English. At the end of semester 1, they showed some progress. The key to my success in changing their attitudes was that I taught with my heart.

In response to my question about the development of his beliefs, he said that at the beginning of his career he had got much knowledge about teaching methods and other educational theories from various courses at his teacher education program. However, his knowledge was just knowledge from other books, not yet entered into his soul. Experience by experience of trying to use the theories selectively, creatively, and eclectically to help his students in terms of learning of different domains had enabled him to construct his own personal theories which gradually transformed into his beliefs. This means that his initial knowledge has partially then become his belief. Seeing from the decision-action perspective, I would say that knowledge and belief can be put in a continuum (Figure 1), with knowledge in the one end and belief on the other end. Knowledge does not necessarily drive action, while knowledge which has crystalized well with its convincingly successful experiences of applying it becomes a belief which drives action. In this case knowledge through empirical experiences crystalizes well into a belief, which is a personal possession. This certainly needs further researching.

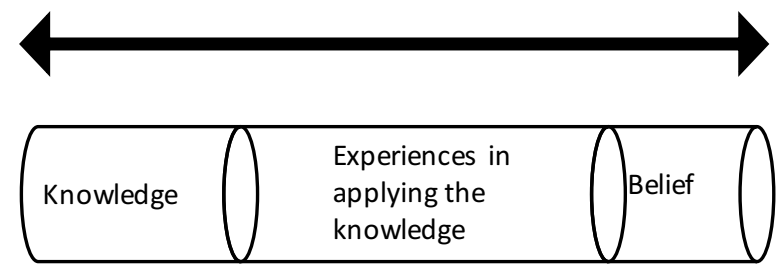

Figure 1. The Knowledge-Belief Continuum.

The teacher's teaching practice and results. The teacher's beliefs and claimed actions presented above were supported by his students' learning achievements. On my request, he sent me some recordings of the final oral English exam in which I found a convincing evidence of his students' English proficiency. Upon receiving them, I rushed to watch them one by one. I watched the students enacting their parts in the discussion on 'poverty alleviation', with one student acting a director from the World Bank, another as the Minister of Finance, and another as the top figure of an Indonesian central bank, another as an economic expert, and the last one as the moderator. They all spoke fluently and relatively accurately, showing a high level of self-confidence. The interaction went on smoothly and naturally. I watched other two videos and found almost the same evidence. This made me more convinced of his being a special teacher, who keeps his words. 
Being amazed by the quality of his students' English, I made some inferences. Such an achievement of learning English must be attained through an instructional approach which ensures (a) the balanced development of accuracy and fluency, (b) the development of students' self-confidence, (c) the students' willingness to communicate; (d) reward, and (e) student empowerment. In other words, the instructional approach must have applied some principles: the principle of automaticity with the ultimate result of fluent and accurate speech, the principle of reward which helps students build their self-confidence, the principle of selfregulate learning in which students set their own goal, the principle of interaction which enhances the students' willingness to communicate, the principle of agency which helps the students to realize their potentials and empower them (Brown \& Lee, 2015: 66-85). Through our long phone conversation, I found that my inferences were correct and this was further supported by what I observed in his classroom.

Thinking about my inferences, I became more curious about his teaching practice. Around six weeks later I called to tell him that within that week I would fulfil his invitation to visit his school on my way home from a school visit in a sub-district near his school. He replied happily and said that Wednesday would be good because on that day the students were scheduled to present their posters they had completed as their English projects.

Accompanied by my assistant, I arrived early at his school and the principal, who was informed of my visit, welcomed me and conversed with me for a while. In response to my question, he briefed me about the development of the school, which he had given due attention. He said that he supported the EFL teacher's creative efforts to facilitate the students' learning; he was pleased with the results of the English exams, both local and national. Our conversation stopped when the bell rang. The teacher then walked us to his classroom.

As soon as we entered the classroom, the teacher introduced me in English to the class, who seemed to be accustomed to being visited. He said that: (1) students had completed a group project of making posters on current issues, two of which were "Save our Planet" and "Let's Live a Healthy Life"; (2) in groups, they planned their poster projects and then implemented what they had planned; and (3) they now had to report the results of their poster projects.

We sat in the back row in his class, doing a non-participant observation. The teacher sat in the back but on the other side of the classroom, with a notebook and a pen in his hand. Everything was well organized, with students seeming to know what to do. They might have been familiar with the project-based learning to create a more authentic situation of using English. The following is the vignette of the process of poster presentation in which English was used from the very beginning to the end.

The five groups in turns presented the group poster as the first activity. Each group had a spokesperson, who fluently talked about the content of the poster with no interruption at all. Each had a promoting tone with a pretty high level of self-confidence. This was followed by a QACs (questions-answers-comments). Interestingly, members of different groups tried to seize the opportunity to ask questions and some students even responded to other students' comments. Before moving to the next activity, the teacher said that he was happy and proud with their performance but wanted, them to be better and therefore provided a corrective feedback. Asking the students to listen and think about the grammar, he repeated the wrong sentence. The student who said the sentence could correct it. After that, each group sent two members acting as visitors from some country to visit another group. The groups visited one another, with the host group promoting the issue through the poster. They were also to exchange information on the issues raised in the poster between the guest country and the host country (Indonesia). The next activity was for the groups to discuss internally what they had learned. This was followed by an activity in which groups told one another what they had learned that day. In between the activities, the teacher gave indirect corrective feedback if students made mistakes and direct corrective feedback if they made errors. The last activity was a reflection. All activities were done in English.

\section{Box 1. The process of presenting posters of the project result.}

The vignette above indicates that the students communicated with one another in an authentic situation though the authenticity of more pedagogical than genuine. The presenting students seemed to concentrate on conveying meanings because they had to use their own words. The quality of their English was above my expectation in terms of accuracy (vocabulary, pronunciation and grammar) and fluency. The teacher appropriately combined the development of fluency and accuracy. While making some notes, he let the students speak without any interruption so that they could concentrate on expressing what they meant. Only after one 
activity was finished, before starting the following activity, did he give either indirect or direct corrective feedback, preceded by some praise with thumbs up. When I checked with some students, they confirmed that they were often involved in projects like this and other activities in which they had to practice their English. They said that they were happy because the teacher appreciated what they had done and provided help when they needed it. They admitted that they had to work hard to reach the target of finishing the project they set themselves. What they were happiest about was that they could speak English. The students were involved in applying the strategic investment (Brown \& Lee, 2015: 51). My inferences above were proven true.

When I asked the teacher if he was concerned with the time consumption in implementing PBL (project-based learning), he admitted that to be able to implement it and also other group activities emphasizing the use of English he had a make a good plan of the whole year and informed students of this plan. He said when students were well informed of the planned activities, they were more prepared and therefore more cooperative. Summarizing his approach to teaching, he stated confidently that through PBL: (a) the students has ample opportunity to use English for communication purposes; (b) they developed their own learning skills; and (3) this model of learning facilitated the instilment of important values such as independence, diligence, communication, open-mindedness, discipline, cooperation, and responsibility, which were part of education. Concluding, he said that the teaching of English could achieve beyond English proficiency.

The benefits of PBL mentioned above is in line with what has found by researchers concerning PBL. Some benefits of implementing PBL have accumulatively been presented on literature: (1) Through their engagement in purposeful communication to accomplish authentic communicative activities, students improve their English language skills (Levine, 2004), learn the four skills in integration (Stoller, 2006), have the opportunity to use English in a relatively natural context (Haines, 1989), and participate in meaningful activities which require authentic language use, which involve problem-solving skills and foster learning to learn (Brown et al, 1993); (2) Through their involvement in the process of planning the project and implementing it leading to the end-product of project-work, students have opportunities to develop their self-confidence and independence (Fried-Booth, 2002), enhance their self-esteem, and develop positive attitudes toward learning (Stoller, 2006:27), improve their autonomy (Skehan, 1998), increase their social, cooperative skills, and group cohesiveness (Coleman, 1992; Papagiannopoulos et al, 2000: 36-37); (3) As project work progresses according to students' interests in specific context (Kriwas, 1999: 149), students' motivation, engagement and enjoyment are enhanced (Lee, 2002), and therefore their learning is also promoted (Brophy, 2004); (4) students' involvement in doing the project can support the development of their higher-order critical thinking and problemsolving skills (Allen, 2004), which are very important, as they are life-long, transferable skills to settings outside the classroom; and (5) Project work can encourage motivation, foster group cohesiveness, increase expectancy of success in the target language, achieve "a rare synthesis of academic and social goals", reduce anxiety, increase the significance of effort relative to ability, and promote effort-based attributions (Dornyei, 2001:100-101). The researched teacher claimed that his students also enjoyed some of these benefits, but this is limited to his personal observations.

What I observed in his class provides evidence for his creative and innovative teaching. He seemed to enjoy freedom to create activities and innovate ways of teaching. His action aired an empowerment approach and this might have resulted in his students' confidence. I was indeed impressed by the level of his students' confidence during the activities. They were not disturbed at by all our presence. When I asked him about this, he said, "Well, they are accustomed to the presence of guests observing them learning. I often invite a native speaker of English to come here, to observe and then give suggestions, and talk with them." "I'm really impressed by the level of vocabulary they've mastered." "Well, I provided them with a lot of reading materials for their extensive reading, Ma'am." "Including your books?" "Yes, but a lot more." "No wonder," I replied. This is in line with what Nation (2009) whose strands include fluency development.

Concerning the students' self-discipline, the teacher said, "I make various efforts, one of which a dialogic discussion, to make them aware of the importance of self-discipline and thus their need for training themselves to be self-disciplined. With selfdiscipline, they do not lose any time and therefore they learn more and then achieve more. I taught them self-discipline by example. For instance, I'm always on time and I keep the schedule of giving them feedback. I also emphasize the development of their autonomy since later on in real life everyone has to be independent, taking charge of everything about matters of life. For this, I let them plan their project and set the target." "Is there anything else you emphasize so far?" "Yes, this one. When I begin to teach a new group of students, I ask them to mention their ideals. Some of them do not have any yet. I then encourage them to think of anything they want as their ideal. Finally, everyone has one." "What do you do after that?" "I tell them that it's important for everyone to pursue it. In relation to this, I very often remind them that mastering English may pave the way to making their dream come true. In other words, it's a prerequisite to their bright future." His belief and practice of training his students to selfdisciplined, resulting in better and more learning is in line with Gorbunovsa, Kapenieksb, and Cakulac (2016) who found that selfdiscipline has positive impact on learning outcomes. 
The teacher admitted that success after success made by his students had helped strengthen his belief that every student can be successful if the teaching lends support and facilitates their learning how to learn. By success he means "student's ability and skill to speak English communicatively." This is a point worth considering since the EFL environment outside the classroom and school provides very little, if any at all, exposure to English; some words are used in advertisements, sometimes together with the local language. His struggles to create communicative activities through teaching approach such as PBL has paid off. This has been supported by feedback from some alumni, who managed to contact him and confessed that only after entering the job did they realize the invaluable contribution he had made through "forcing" them to speak English in a project and also self-discipline training. This had led to his stronger belief "that his duty is to show alternative ways to learn and be ready to lend his hands when needed." In short, this particular teacher has reached a professional maturity.

In the last contact I made to check if he had changed his belief due to the pandemic condition, he said that he still had the same belief, but had to adapt everything and work harder with the online learning. Heha d tried his best to help his students learn, but admitted that he could not provide as many and immediate feedbacks in online learning during the pandemic situation as in offline learning before. Before the COVID-19, he could categorize mistakes for more efficient and systematic feedbacks in the classroom so that the time could be saved. With online learning, the system does not give opportunity to provide group feedback in a quick way due to limited maneuver of the system. However, he said that he remained committed to helping his students learn as well as he could. This is in line with what Buehl and Beck (2015) have found from reviewing some works that in enacting their beliefs, teachers might be confronted with challenges posed by classroom-level factors, such as student ability, student attitudes, classroom management, class size, but the challenges do not prevent them from finding ways to enact their beliefs.

The researched teacher's professional level can also be seen from his achievements grouped into four here: (1) his participation in various seminars/conferences and workshops both as presenting participants and non-presenting participants, some of which were abroad; (2) his participation in the Citizen Exchange Program: A Global Cultural Initiative Summer 2009 Landmarks of American Culture and History Workshop in the USA. (I, in my capacity as the Head of the Provincial Office of Education, followed the process of his departure); (3) his accomplishment of writing 181 books, i.e. 87 (48.08\%) books on the local legends or folklores in English, 49 (27.07\%) books of English learning materials, 14 (7.73\%) book strategies/ways of learning English, and 27 (14.92\%) books on English test preparation; and (4) his success of leading English teacher professional development through Whatsapp Group (WAG) communication in English, with more than 2000 members. This is a good strategy to compensate for the absence of English communicative situations. In WAG the members are to use English, which is a good strategy to maintain their English proficiency since as mentioned earlier, after 15 years of experiences the EFL teachers begin to lose their English proficiency (Lie et el., 2019).

Considering how the teacher believed strongly that his students can learn, the researched teacher belongs to what Hattie (2012) has termed as "expert-teacher." An expert teacher: (1) can identify the most important ways in which to represent the subject that they teach; (2) is proficient at creating an optimal classroom climate for learning; (3) monitors learning and provide feedback; (4) believes that all students can reach the success criteria; and (5) influences surface and deep student outcomes (pp. 25-27). Feature 1 was evident in his consistent practice of helping his student to learn to use English for communication purposes, Feature 2 in creating a non-threatening atmosphere, Feature 3 in monitoring his students' learning and providing feedback, Feature 4 in his belief and action with its result; and Feature 5 in caring for the instilment of performance and moral values. Hattie contends that a teacher with a long experience is not necessarily an expert teacher because s/he just does the same thing all-over her/his career. Beside belonging to Hattie's category of expert teacher, the researched teacher can also be categorized as a post-method teacher (Kumaravadivelu, 2001), who theorizes his teaching practice and practices what they have theorized. The teacher has found his own way of teaching, which he has sought from the beginning of his career. His various professional actions driven by his beliefs are in line with Fives and Buehl (2012) who state the teachers may used their beliefs to: (1) filter and interpret information, (2) frame a specific problem or task (e.g., lesson planning), and (3) guide immediate action.

\section{Conclusion}

The discussion of the findings above lead to the following conclusions. In the demanding system of education in Indonesia, the researched teacher has done his best to achieve the EFL curriculum goal in his own way, following his beliefs. The researched teacher's beliefs have: (1) been formed through reflective and innovative experiences in applying eclectically theories he had got from his teacher education; (2) driven him to take various professional actions to enact them; (3) served different roles related to their knowledge and actions.

The above conclusions imply the importance of reflective experiences and freedom to construct personal professional knowledge. In relation to this, the EFL teacher education should be developed further to ensure that the student teachers are provided with 
ample opportunity to understand various aspects of their teacher education. In this case, Kumaravadivelu' (2012) CARDS is worth considering.

\section{References}

Ahsanu, M., Februansyah, R. \& Handoyo, R.P. (2014). English Basecamp: An Alternative Learning Method for Enhancing Speaking Skill (A Case Study in Kampung Inggris, Pare, Kediri, East Java) Retreived from https://www.atlantispress.com/proceedings/icpm-14/13411

Allen, L., Q. (2004). Implementing a culture portfolio project within a constructivist paradigm. Foreign Language Annals, 37, 232-239.

Anugerahwati, M. \& Saukah, A. (2010). Professional competence of English teachers in Indonesia: A profile of exemplary teachers. Indonesian Journal of English Language Teaching 6(2), 47-59.

Ataveva, M. (2020). Student-Centered Approach (SCA) In English Language Learning: A Case Study of Cambridge International Boarding School Yogyakarta (Unpublished Master's thesis). Yogyakarta: PPs UNY.

Bandura, A. (1997). Self-efficacy: The exercise of control. New York, NY: Freeman.

Borg, M. (2001). Teachers’ beliefs. English Language Teaching Journal 55(2), 186- 188.

Brown, H. D.\& Lee, H. (2015). Teaching by principles: An interactive approach to language pedagogy. New York: Pearson

Buehl, M.M. \& Beck, J.S. (2015). The relationship between teachers' beliefs and teachers' practices. In Fives, H. \& Gill, M.G. (Eds.). International Handbook of Research on Teachers'Beliefs, pp. 66-84. London: Routledge.

Celce-Murcia, M. (2007). Rethinking the role of communicative competence in language teaching. In Soler, E.A. \& Jorda, M.P.S. (Eds.). Intercultural Language Use and Language Learning. Dordrecht, the Netherlands: Springer.

Coleman, J. A. (1992). Project-based learning, transferable skills, information technology and video. Language Learning Journal, 5, 35-37.

Davidson, M. (2004). Developing performance character and moral character in youth. The Fourth and Fifth Rs: Respect and Responsibility, $10(2)$.

Dörnyei, Z. (2001). Motivational Strategies in the Language Classroom. Cambridge: Cambridge University Press.

Fives, H. \& Buehl, M. M. (2012). Spring cleaning for the "messy" construct of teachers' beliefs: What are they? Which have been examined? What can they tell us? In K.R. Harris, S. Graham, T. Urdan, S. Graham, J.M. Royer, \& M. Zeidner (Eds.) APA educational psychology handbook. Vol 2: Individual differences and cultural and contextual factors (pp. 471-499). Washington, DC: American Psychological Association. https://doi.org/10.1037/13274-019

Fragoulis, I. (2009). Project-Based Learning in the Teaching of English as A Foreign Language in Greek Primary Schools: From Theory to Practice. English Language Teaching, 2(3), 113-119.

Fried-Booth, D., L. (2002). Project work (2nd ed.). New York: Oxford University Press.

Gorbunovs, A., Kapenieks, A. \& Cakula, S. (2016). Self-discipline as a Key Indicator to Improve Learning Outcomes in elearning Environment. Procedia - Social and Behavioral Sciences, 231, 256-262.

Haines, S. (1989). Projects for the EFL classroom: Resource material for teachers. Walton-on-Thames, UK: Nelson.

Hattie, J. (2012). Visible Learning for Teachers: Maximizing Impact on Learning, London: Routledge. 
Hyland, K. (2007). Genre pedagogy: Language, literacy, and L2 writing instruction. Journal of Second Language Writing, 16, 148-164. https://doi.org/10.1016/j.jslw.2007.07.005

Irambona, A. \& Kumaidi (2015). The Effectiveness Of English Teaching Program In Senior High School: A Case Study. Retrieved from https://journal.uny.ac.id/index.php/reid/article/view/6666

Kartikarini, T. (2020). Promoting Young Learners' English Literacy Through A Reading Log Program. An unpublished Master's thesis. Yogyakarta: PPs UNY.

Khader, F. R. (2012). Teachers' Pedagogical Beliefs and Actual Classroom Practices in Social Studies Instruction. American International Journal of Contemporary Research, 2(1), 73-92.

Khader, F.R. (2012). Teachers' pedagogical beliefs and actual classroom practices in social studies instruction. American International Journal of Contemporary Research, 2(1), pp.72-93.

Khasasah, U.L. (2018). Analisis Implementasi Sistem Zonasi: Perspektif Stakeholder Sekolah [An Analysis of the Zoning System: School Stakeholders' Perspective] (Unpublished master's thesis). Malang, Indonesia: UIN Mulana Malik Ibrahim.

Kriwas, S. (1999). Environmental education, a handbook for educators. Athens: Ministry of Education.

Kumar, C. P. (2013). The eclectic method-theory and its application to the learning of English. International Journal of Scientific and Research Publications, 3, 1-4. https://doi.org/10.15373/22778179/July2014/173

Kumaravadivelu, B. (2001). Toward a post-method pedagogy. TESOL Quarterly, 35, 537-560. https://doi.org/10.2307/3588427

Kumaravadivelu, B. (2012). Language Teacher Education for a Global Society: A Modular Model for Knowing, Analyzing, Recognizing, Doing and Seeing. London \& New York: Routledge.

Lauder, A. (2008). The status and function of English in Indonesia: A review of key factors. Makara, Sosial Humaniora, $12(1), 9-20$

Lazarus, A., \& Beutler, L. (1993). On technical eclecticism. Journal of Counseling \& Development, 71, $381-385$. https://doi.org/10.1002/j.1556-6676.1993.tb02652.x

Lee, I. (2002). Project work made easy in the English classroom. Canadian Modern Language Review, 59, $282-290$.

Lee, I. (2009). Ten mismatches between teachers' beliefs and written feedback practice. ELT Journal, 63(1), 13-22. https://doi.org/10.1093/elt/ccn010

Leeds-Huwitz, W. (2013). Intercultural competences: conceptual and operational framework. Paris: UNESCO.

Lengkanawati, N. (2005). EFL Teachers' competence in the context of English curriculum 2004: Implications for EFL teacher education. TEFLIN Journal, 26(1): 79-92.

Levine, G., S. (2004). Global simulation: a student-centered, task-based format for intermediate foreign language courses. Foreign Language Annals, 37, 26-36.

Lie, A. et al (2019). English proficiency of secondary school teachers in Indonesia. Beyond Words, Vol. 7(2). Pp.86-100.

Lubis, A.H. et all (2018). Students' experiences of learning English in Indonesia: Some effective and ineffective ways. International Journal of Education, 3(2), 101-111.

Lubis, A.H. (2018). Reflective teaching toward EFL teachers' professional autonomy: revisiting its development in Indonesia. International Journal of Education, 11(1), 35-49. 
Mahmud, B. (2017). Teacher solution to solve the problem in implementing the activities used in teaching speaking English in Islamic boarding school Darussalam Gontor. Retrieved from https://eprints.umk.ac.id/7007/11/The-2ndTEYLIN-ilovepdf-compressed-90-97.pdf

Marcelino, M. (2008). English language teaching in Indonesia: A continuous challenge in education and cultural diversity. TEFLIN Journal, Vol. 19(1), 57-69.

Mattarima, K \& Handan, A.R. (2011). The teaching constraints of English as a foreign language in Indonesia: The context of school based curriculum. Sosiohumanika, 4(2), 287-300.

Mellow, J. D. (2002). Towards principled eclecticism in language teaching: The two-dimensional model and the centering principle. Retrieved from http://tesl-ej.org/ej20/a1.html

Miles, M.B., Huberman, A.M., \& Saldana, J. (2014). Qualitative Data Analysis: A Methods Sourcebook and the Coding Manual for Qualitative Researchers ( $3^{\text {rd }}$ ed.). Thousand Oaks, CA: Sage Publications.

Nation, I.S.P. (2009). Teaching ESL/EFL Reading and Writing. New York \& London: Routledge.

Papagiannopoulos, K. Simoni, E, and Fraggoulis, I. (2000). Local history in the framework of teaching, Athens: OEDB. (in Greek).

Pourhosein Gilakjani, A. (2012). EFL Teachers' Beliefs toward Using Computer Technology in English Language Teaching. Journal of Studies in Education, 2(2), 62-80. https://doi.org/10.5296/jse.v2i2.1174

Renandya, W., Hamid, F. \& Nurkamto, J. (2018). English language proficiency in Indonesia: Issues and Prospects. The Journal of Asia TEFL, 15(3), 618-629.

Richards, J.C. (2006). Communicative language teaching today. Cambridge: Cambridge

Rokeach, M. (1968). Beliefs, attitudes, and values: A theory of organization and change. San Francisco: Jossey-Bass.

Schon, D. (1983) The Reflective Practitioner: How Professionals Think in Action, New York: Basic

Schon, D. (1987) Educating the Re ective Practitioner, San Francisco: Jossey-Bass.

Schon, D. (ed) (1991) The Reflective Turn: Case Studies in and on Educational Practice. New York: Teachers' College Press.

Skehan, P. (1998). A cognitive approach to language learning. Oxford: Oxford University Press.

Songbatumis, A. M. (2017). Challenges in teaching English faced by teachers English teachers at MTsN Taliwang Indonesia. Journal of Foreign Language Teaching \& Learning, 2(2), 54-67.

Stoller, F. (2006). Establishing a theoretical foundation for project-based learning in second and foreign language contexts. In Beckett, G., H. \& P. C. Miller (Eds.), Project-Based Second and Foreign Language education: past, present, and future (pp. 19-40). Greenwich, Connecticut: Information Age Publishing.

Sulistiyo, U. (2015). Improving English as a foreign language teacher education in Indonesia: The case of Jambi University (Doctoral thesis). Melbourne: RMIT University.

Toyama, K. (2011). There are no technology shortcuts to goo education. Educational Technology Debate. Retrieved from edutechdebate.org

Vygotsky, L. (1986) Thought and Language, tr. and ed. A. Kozulin, London: MIT Press.

Vygotsky, L. S. (1986). Thought and language. Cambridge, MA: MIT Press. 
Widiati, U., \& B.Y. Cahyono. (2006). The Teaching of EFL Speaking in the Indonesian context: the state of the art. Bahasa Dan Seni, 34(2), 269-291.

$\mathrm{Xu}, \mathrm{L}$. (2012). The role of teachers' beliefs in the language teaching-learning process. Theory and Practice in Language Studies, 2(7), 1397-1402.

Yang, N. D. (1992). Second language learners' beliefs about language learning and their use of learning strategies: A study of college students of English in Taiwan. Unpublished doctoral dissertation, University of Texas, Austin.

Yulia, Y. (2013). Teaching challenges in Indonesia: Motivating students and teachers' classroom language. Indonesian Journal of Applied Linguistics, 3(1), 1-16.

Yusny, R. (2013). ELT in Indonesian context: issues and challenges. Englisia, 1(1), 81-99.

Zheng, H. (2009). A Review of Research on EFL Pre-Service Teachers' Beliefs and Practices. Journal of Cambridge Studies, 4(1), 73-81. 